\title{
QUEEN'S
UNIVERSITY
BELFAST
}

\section{Siccitas magna ultra modum: Examining the occurrence and societal impact of droughts in Prehistoric Ireland}

Plunkett, G., Brown, D. M., \& Swindles, G. T. (2020). Siccitas magna ultra modum: Examining the occurrence and societal impact of droughts in Prehistoric Ireland. Proceedings of the Royal Irish Academy: Section C, Archaeology, Celtic Studies, History, Linguistics, Literature, 120C, 83-104.

https://doi.org/10.3318/priac.2020.120.03

Published in:

Proceedings of the Royal Irish Academy: Section C, Archaeology, Celtic Studies, History, Linguistics, Literature

Document Version:

Peer reviewed version

Queen's University Belfast - Research Portal:

Link to publication record in Queen's University Belfast Research Portal

Publisher rights

( 2019 Royal Irish Academy. This work is made available online in accordance with the publisher's policies. Please refer to any applicable terms of use of the publisher.

\section{General rights}

Copyright for the publications made accessible via the Queen's University Belfast Research Portal is retained by the author(s) and / or other copyright owners and it is a condition of accessing these publications that users recognise and abide by the legal requirements associated with these rights.

Take down policy

The Research Portal is Queen's institutional repository that provides access to Queen's research output. Every effort has been made to ensure that content in the Research Portal does not infringe any person's rights, or applicable UK laws. If you discover content in the Research Portal that you believe breaches copyright or violates any law, please contact openaccess@qub.ac.uk. 


\title{
SICCITAS MAGNA ULTRA MODUM ${ }^{1}$ : EXAMINING THE OCCURRENCE AND SOCIETAL IMPACT OF DROUGHTS IN PREHISTORIC IRELAND
}

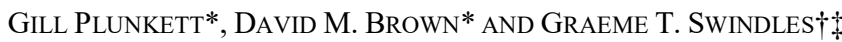

*Archaeology and Palaeoecology, School of Natural and Built Environment, Queen's University Belfast, Northern Ireland.

$\dagger$ Geography, School of Natural and Built Environment, Queen’s University Belfast, Northern Ireland. $\ddagger$ Ottawa-Carleton Geoscience Centre and Department of Earth Sciences, Carleton University, Ottawa, Ontario, Canada.

\section{ABSTRACT}

When considering past human-environment relationships in Ireland, we rarely consider the potentially detrimental effects of drought on populations. The summer of 2018 drew attention, however, to some of the ways in which reduced precipitation can impact on societies, even in an oceanic setting such as Ireland. Here, we examine ways in which we can identify the past occurrence of droughts through palaeoenvironmental records. We focus on three time intervals (c. $6200 \mathrm{BC}, 3200 \mathrm{BC}$ and $900 \mathrm{BC}$ ) for which there is evidence for centennial-scale droughts - drought phases - and consider the available archaeological and palynological records to evaluate whether the droughts may have triggered economic responses or population collapses. We find little evidence to confirm that any of these events undermined the subsistence base to the extent of triggering population collapse. We briefly explore alternative mechanisms by which the drought phases might have impacted upon human perception of their environment.

\section{Introduction}

Ireland is not a location known for its droughts. Rather, its frequent rainfall is internationally infamous, and a common source of conversation and consternation across the island. Yet the atypical hot, dry summer of 2018 (lasting from June to August), while lauded by many inhabitants, brought unexpected hardship to farmers, as grass growth declined and led to a shortage of fodder, and crops risked failing due to a lack of irrigation. ${ }^{2}$ There were health consequences too, as larger than usual numbers of individuals presented to hospitals with severe cases of sunburn, ${ }^{3}$ and in at least one instance, a child was admitted with a rare skin disease that may have been aggravated by the unusual heat. ${ }^{4}$ All this transpired just months

*Author's email: G.Plunkett@qub.ac.uk

ORCID iD: https://orcid.org/0000-0003-1014-3454

doi: https://doi.org/10.3318:/PRIAC.2020.120.03

${ }^{1}$ This reference (translated 'An abnormally great drought') is from the Annals of Ulster, AD 764.7, celt.ucc. ie//published/T100001A/index.html.

${ }^{2}$ Rebekah Logan, 'NI Heatwave is posing challenges for some farmers', BBC News NI (3 July 2018), www.bbc. co.uk/news/uk-northern-ireland-44685611; Joe Leogue, 'Warm weather to continue but at cost to farmers', Irish Examiner (2 August 2018), www.irishexaminer.com/breakingnews/ireland/warm-weather-toreturn-but-at-cost-to-farmers-859400.html.

${ }^{3}$ Ali Gordon, 'Heatwave sunburn: 220 people treated in NI hospitals', BBC News NI (20 July 2018), www.bbc. co.uk/news/uk-northern-ireland-44808082.

${ }^{4}$ Aisha Ijaz et al., 'The hazards of an Irish heatwave; ecthyma', Archives of Disease in Childhood 104 (Supplement 3) (2019), A:246. 
after the 'Beast from the East' saw an anticyclonic arctic airmass bring exceptional cold and heavy snow that caused considerable societal and economic disruption. ${ }^{5}$

While the extreme summer of 2018 may be symptomatic of the climate crisis that currently confronts us, droughts have featured in the Irish climate in the past. Instrumental climate records are of course a relatively recent innovation; for Ireland, longest-running continuous sequence of weather data - from Armagh Observatory - was established a little over two centuries ago, ${ }^{6}$ within which time the climate has emerged from the Little Ice Age and post-Industrial warming began. For an understanding of longer-term natural climate behaviour, one must turn to historical and palaeoenvironmental proxy records. An entry in the Annals of Ulster for the year AD 749 tells of 'Snow of unusual depth so that nearly all the cattle of the whole of Ireland perished, and the world afterwards was parched by unusual drought', ${ }^{7}$ extremes that are rather reminiscent of the spring and summer of 2018 . The consequences of droughts for farmers can also be gleaned from earlier chronicles: for example, the Annals of Ulster records for the year AD 773 an 'Unaccustomed drought and heat of the sun so that nearly all bread [grain] failed. Abundance of oak-mast afterwards'. These references serve as salutary reminders of the detrimental societal impacts even one dry season can trigger. What then if such conditions persisted over many years as 'drought phases'? Palaeoenvironmental data suggest that they did.

One of the upsides of Ireland's pervasive wet climate is that it has resulted in ample bogs whose distinctive qualities have allowed them to capture records of past environmental change as they formed and accumulated peat through the millennia. Specifically, the inhibition of biological decay has ensured the partial preservation of plant and animal remains that once lived on the bogs, communities of which were strongly influenced by the degree of bog surface wetness. In peatlands that are independent of the water table (raised and blanket bogs), bog surface wetness is at least in part governed by climate: the drier and/or warmer the conditions, the drier the bog surface, while the colder and/or wetter the condition, the higher the water level at the bog surface. While the degree of wetness is therefore a product of both temperature and precipitation, it is thought that summer effective precipitation is the leading variable reflected in palaeohydrology records. ${ }^{9}$ Examining changes in biotic communities preserved within the peat, linked as they are to bog surface wetness, can therefore yield indirect (proxy) records of past climate variability (Fig. 1). During drier phases, the peat itself will undergo a greater degree of decomposition (humification), so humification levels too are an index of past conditions. Subfossilised remains of bog oaks and pines also give insights into changing hydrological conditions through the dates of their establishment and die-off. Successful germination and establishment of such trees on bog surfaces will only occur during periods of lower water tables. ${ }^{10}$

${ }^{5}$ Met Éireann, 'Storm Emma: An analysis of Storm Emma and the cold spell which struck Ireland between the 28th of February and the 4th of March 2018',

www.met.ie/cms/assets/uploads/2019/02/EmmaReport2019.pdf

${ }^{6}$ C.J. Butler et al., 'Air temperatures at Armagh Observatory, Northern Ireland, from 1796 to 2002', International Journal of Climatology 25 (2005), 1055-79: 1056

${ }^{7}$ Annals of Ulster 748.3 , celt.ucc. ie//published/T100001A/index.html. This date has been corrected to AD 749 following synchronisation of sources by D.P. McCarthy, Chronological synchronisation of the Irish Annals (4th edition), www.scss.tcd.ie/misc/kronos/chronology/synchronisms/Edition $4 / \mathrm{K}$ trad/K_synch.htm

${ }^{8}$ Annals of Ulster 773.4 , celt.ucc. ie//published/T100001A/index.html.

${ }^{9}$ D.J. Charman et al., 'Testing the relationship between Holocene peatland palaeoclimate reconstructions and instrumental data at two European sites', Ouaternary Science Reviews 23 (2004), 137-43.

${ }^{10}$ D.N. McVean, 'Ecology of Scots pine in the Scottish Highlands', Journal of Ecology 51 (1963), 671-86: 672; J.R. Pilcher et al., 'Hydrological data from the long Irish subfossil oak records', in J.S. Dean, D.M. Meko and T.W. Swetnam (eds), Tree rings, environment, and humanity. Proceedings of the International Conference, Tucson, Arizona, 17-21 May 1994. Radiocarbon (special issue) (1996), 259-64; A.K. Moir et al. 
Using a multi-proxy approach on peat sequences extending back to the Early Bronze Age (2500 BC), Swindles, Blundell and Roe identified three periods of potentially extended drought dating respectively to $1150-800 \mathrm{BC}, 320 \mathrm{BC}-\mathrm{AD} 150$ and $\mathrm{AD} 250-470$, in addition to an extended period of drought in the post-Industrial era. ${ }^{11}$ The climate signal in the upper levels of the bogs is, however, confounded by direct human impacts on bog hydrology, such as peatland drainage. A subsequent study entailing a wider selection of sites upheld the identification of these intervals as drier phases ${ }^{12}$ although Plunkett saw the first of these events as two distinct dry events, separated by a wet shift. ${ }^{13}$ These findings imply that extended drought phases did indeed transpire in the past.

Here we examine three time-intervals for which there has been posited evidence for droughts phases during Irish prehistory, and for which we can avail of precisely-dated data from bog oaks and pines ${ }^{14}$ to evaluate the evidence for and timing of these events (Fig. 2). ${ }^{15}$ We consider the impacts these changes might have had on human populations, specifically from an economic perspective, and examine whether environmentally-driven interpretations stand up to critical analysis. The locations of key sites producing subfossilised oaks and pines referred to in the text are shown in Fig. 3.

\section{The 8.2 ka Event}

The ' 8.2 ka Event' is thought to be a potentially global phenomenon characterised by a rapid cooling lasting $c .150$ years, possibly the most extreme climate perturbation since the end of the last glacial period. ${ }^{16}$ It is dated in Greenland ice cores to $8247 \pm 47$ years before present (BP), ${ }^{17}$ or approximately $6300 \mathrm{BC}$, although this date is subject to revision. ${ }^{18}$ The climate anomaly has had little recognition in Irish palaeoecological records: difficulties in dating sedimentary records with such high precision, coupled with the relatively short duration of the event, renders it challenging to discern any expression of a climate perturbation at this time. A speleothem-derived temperature anomaly at $8300 \pm 120$ years BP reported from Crag

'Dendrochronological evidence for a lower water-table on peatland around 3200-3000 BC from subfossil pine in northern Scotland', The Holocene 20 (2010), 931-42: 937.

${ }^{11}$ G.T. Swindles et al., 'A 4500-year proxy climate record from peatlands in the north of Ireland: the identification of widespread summer “drought phases”?', Quaternary Science Reviews 29 (2010), 1577-89.

${ }^{12}$ G.T. Swindles et al., 'Centennial-scale climate change in Ireland during the Holocene', EarthScience Reviews 126 (2013), 300-20: 316.

${ }^{13}$ Gill Plunkett, 'Tephra-linked peat humification records from Irish ombrotrophic bogs question nature of solar forcing at 850 cal. yr BC', Journal of Quaternary Science 21 (2006), 9-16.

${ }^{14}$ Dendrochronological data are drawn from the Belfast Master Chronology, a database comprising over 2,500 archaeological and natural timbers collected and dated by various workers from the 1970s. These timbers were measured and cross-correlated using standard methodologies: M.G.L. Baillie, Tree-ring dating and archaeology (London, 1982); M.A.R. Munro, 'An improved algorithm for crossdating tree-ring series', Tree Ring Bulletin 44 (1984), 17-27; J.R. Pilcher et al., 'A 7272-year tree-ring chronology from western Europe', Nature 312 (1984), 150-2; D.M. Brown et al., 'Dendrochronology - the absolute Irish standard', Radiocarbon 28 (1986), 279-83.

${ }^{15}$ See Lisa Coyle-McClung and Gill Plunkett, 'Cultural change and the climate record in Final Prehistoric and early medieval Ireland', Proceedings of the Royal Irish Academy C (accepted), for consideration of the Iron Age droughts identified by Swindles et al., 'Centennial-scale climate change'.

${ }^{16}$ R.B. Alley et al., 'Holocene climatic instability: A prominent, widespread event $8200 \mathrm{yr}$ ago', Geology 25 (1997), 483-6.

${ }^{17}$ E.R. Thomas et al., 'The 8.2 ka event from Greenland ice cores', Ouaternary Science Reviews 26 (2007), 70-81.

${ }^{18}$ In this paper, primacy is given to the $\mathrm{AD}-\mathrm{BC}$ timescale, with 'cal. $\mathrm{BC}$ ' differentiating ${ }^{14} \mathrm{C}$-derived dates from absolute dates derived from precisely-dated tree-ring chronologies; the term $\mathrm{BP}$ (before present) is used only with reference to events that are so-named. 
Cave, Co. Kerry, ${ }^{19}$ has since been shown to be the result of a data calibration issue..$^{20}$ However, the germination of pines - precisely dated using dendrochronology — on bogs in the north of Ireland strongly points to a change towards drier conditions shortly after $6250 \mathrm{BC} ; 21$ trees continued to establish on the bogs over the next 150 years, after which it appears rising water levels prevented their successful establishment. A 15- to 20-year-long growth downturn can been seen in the pine growth-rings at $6070 \mathrm{BC}$ and signals a further climate impact, likely a shift to cooler summer temperatures. All in all, it would appear that Ireland experienced a $c$. 150 -year phase of colder, drier conditions around $6250 \mathrm{BC}$, with perhaps a more severe episode of cold conditions around $6120 \mathrm{BC}$. The findings accord with multi-proxy records from Lake Holzmaar, Germany, where the 8.2 ka Event manifested as reduced winter and summer precipitation, as well as cooler summers. ${ }^{22}$

From an Irish archaeological perspective, the climate anomaly occurs within the Mesolithic period. For a long time dominated by consideration of lithic technology and site functions - lithic scatters representing the bulk of the archaeological assemblage, with a notable dearth of known structural remains - our understanding of the Irish Mesolithic has increased considerably in the last two decades, with the discovery of sophisticated fish traps in wetland locations, evidence for woodland management, ritualised behaviour and burial, ${ }^{23}$ as a result of which more nuanced perspectives on the Irish Mesolithic are emerging. ${ }^{24}$ Drawing upon published ${ }^{14} \mathrm{C}$ dates from Irish Mesolithic sites, Riede and colleagues have interpreted fluctuations in the number of dated archaeological sites as indications of changing population densities, ${ }^{25}$ an approach based on the premise that the more people there are in an area, the more sites they will leave behind for archaeologists to discover and date. They argue that dips in population coincide with climatic perturbations, including the $8.2 \mathrm{ka}$ Event. Wicks and Mithen have similarly argued for a demographic impact in the Mesolithic of western Scotland. ${ }^{26}$ Conversely, using a Bayesian approach to examine the probability that

${ }^{19}$ Frank McDermott, D.P. Mattey and Chris Hawkesworth, 'Centennial-scale Holocene climate variability revealed by a high-resolution speleothem $\delta 18$ O record from SW Ireland', Science 294 (2001), 132831 .

${ }^{20}$ I.J. Fairchild et al., 'Modification and preservation of environmental signals in speleothems', EarthScience Reviews 75 (2006), 105-53.

${ }^{21}$ M.C.A. Torbenson et al., 'Asynchrony in key Holocene chronologies: Evidence from Irish bog pines', Geology 43 (2015), 799-802.

${ }^{22}$ Sushma Prasad et al., 'The 8.2 ka event: Evidence for seasonal differences and the rate of climate change in western Europe', Global and Planetary Change 67 (2009), 218-26.

${ }^{23}$ M. Mossop, 'Lakeside developments in Co. Meath, Ireland: a Late Mesolithic fishing platform and possible mooring at Clowanstown 1', in S.B. McCartan et al. (eds), Mesolithic Horizons II, papers presented at the 7th International conference on the Mesolithic in Europe, Belfast, 2005 (Oxford, 2009), 895-9; Melanie McQuade and Lorna O'Donnell, 'Late Mesolithic fish traps from the Liffey estuary, Dublin, Ireland', Antiquity 81 (2007), 569-84; Tracy Collins, 'Hermitage, Ireland: life and death on the western edge of Europe', in S.B. McCartan et al. (eds), Mesolithic Horizons II, 876-9; Aimée Little et al., 'Stone dead: uncovering early Mesolithic mortuary rites, Hermitage, Ireland', Cambridge Archaeological Journal 27 (2017), 223-43.

${ }^{24}$ Aimée Little, 'Fishy settlement patterns and their social significance: a case study from the northern midlands of Ireland, in S.B. McCartan et al. (eds), Mesolithic Horizons II, 698-705; Nyree Finlay, 'Futile fragments? - some thoughts on microlith breakage patterns', in Nyree Finlay et al. (eds), From Bann flakes to Bushmills: papers in honour of Professor Peter Woodman, Prehistoric Society Research Paper 1 (Oxford, 2009), 22-30.

${ }^{25}$ Felix Riede, 'Climate and demography in early prehistory: using calibrated ${ }^{14} \mathrm{C}$ dates as population proxies', Human Biology 81 (2009), 309-38; Felix Riede, Kevan Edinborough and Mark Thomas, 'Tracking Mesolithic demography in time and space and its implications for explanations of culture change', in Marijn van Gils, Bart Vanmontfort and Marc De Bie, Chronology and evolution in the Mesolithic of $N(W)$ Europe (Cambridge, 2009), 177-94

${ }^{26}$ Karen Wicks and Steven Mithen, 'The impact of the abrupt 8.2 ka cold event on the Mesolithic population of western Scotland: a Bayesian chronological analysis using "activity events" as a population proxy', Journal of Archaeological Science 45 (2014), 240-69. 
site number declined following the 8.2 ka Event, Griffiths and Robinson found that across northwest Europe, including Ireland, there was no evidence for a catastrophic decline in the number of Mesolithic sites at this time. ${ }^{27}$ Indeed, securely-dated Mesolithic sites in Ireland are few and sporadic through time which limits the ability to identify significant demographic oscillations. Riede's dataset includes 94 dates from 22 sites spanning a $>4,000$-year period; this sample size falls well below the threshold generally considered sufficient to produce a statistically reliable summed probability curve. ${ }^{28}$ The technological developmentsspecifically the transition from a microlithic composite tool tradition to that of a larger, broad blade industry - that differentiate the Later Mesolithic from the Earlier Mesolithic certainly point to some sort of transformation, be it in procurement strategies or population, ${ }^{29}$ but Woodman places this shift prior to 8,500 years ago, perhaps between 7000 and 6500 BC. 30 All in all, given the low numbers and ephemeral nature of Mesolithic sites over this interval, interpretations of demographic fluctuations seem imprudent for the time being. Nevertheless, in view of the palaeoenvironmental evidence for a prolonged period of relative drought coupled with colder conditions, it is worthwhile considering the potential impact of the $8.2 \mathrm{ka}$ Event on successive generations, specifically through the availability of food resources.

What we know of Mesolithic subsistence is restricted to the ecofactual evidence from a very small number of sites. Still, and despite Ireland's limited post-glacial fauna and flora, its early settlers evidently availed themselves of a wide range of fish, shellfish, birds, small game and plants. ${ }^{31}$ Warren notes the diversity of diet, not just in terms of the choice of foods available but also in terms of what foods were consumed at which sites. ${ }^{32}$ Given the lack of large game in Ireland, it is perhaps not surprising that fish and shellfish remains dominate ecofactual assemblages.

Attempts to quantify the climate impact of the $8.2 \mathrm{ka}$ Event have tended to focus on temperature changes, with a decline of about $1^{\circ} \mathrm{C}$ suggested for north-west Europe in general. ${ }^{33}$ It is important to consider, however, that conditions prior to the $8.2 \mathrm{ka}$ Event were unlike those of today. At this stage of the Holocene, Ireland's climate may have been more continental, ${ }^{34}$ with greater seasonal differences. How the $8.2 \mathrm{ka}$ Event cooling impacted on temperatures in Ireland has yet to be determined empirically, but the absence of varved lake sequences at this time may imply that winters were not so harsh as to feature frozen lakes for extended periods. Changes in water temperatures - marine and freshwater-may have impinged upon fish stocks or diversity, as might lower lake and river levels and any resultant changes in water chemistry following an extended drought phase. As yet, we have no data with which to evaluate such changes, but recent advances in biomolecular and sedaDNA analysis may in future place us in a position to tackle such questions. Migratory bird patterns may also have been altered, given the spatial scale of the $8.2 \mathrm{ka}$ Event.

${ }^{27}$ Seren Griffiths and Erick Robinson, 'The 8.2 ka BP Holocene climate change event and human population resilience in northwest Atlantic Europe', Quaternary International 465 (2018), 251-7.

${ }^{28}$ A.N. Williams, 'The use of summed radiocarbon probability distributions in archaeology: a review of methods', Journal of Archaeological Science 39 (2012), 578-89.

${ }^{29}$ L.J. Costa, F. Sternke and P.C. Woodman, 'Microlith to macrolith: the reasons behind the transformation of production in the Irish Mesolithic', Antiquity 79 (2005), 19-33.

${ }^{30}$ Peter Woodman, Ireland's first settlers: time and the Mesolithic (Oxford, 2015): 226.

${ }^{31}$ Graeme Warren, "Mere food gatherers they, parasites upon nature...": Food and drink in the Mesolithic of Ireland', Proceedings of the Royal Irish Academy 115C (2015), 1-26; Woodman, Ireland's first settlers.

${ }^{32}$ Warren, "Mere food gatherers they, parasites upon nature...", 23.

${ }^{33}$ Hans Renssen, et al., 'The 8.2 kyr BP event simulated by a global atmosphere-sea-ice-ocean model', Geophysical Research Letters 28 (2001), 1567-70.

${ }^{34}$ F.J.G. Mitchell, 'The Holocene', in C.H. Holland and I.S. Sanders (eds), The Geology of Ireland (Edinburgh, 2009), 397-404. 
From a vegetation perspective, hazelnuts appear to have been a consistent element of the diet through the Irish Mesolithic. Hazel is sensitive to drought, particularly in relation to the successful germination of hazelnuts, although it is capable of vegetative reproduction. ${ }^{35}$ Ghilardi and O'Connell recognise a c. 100 year decrease in Corylus pollen concomitant with increases in Pinus and Betula that they attribute to the $8.2 \mathrm{ka}$ Event, and they note similar phenomena in several other pollen records from the west of Ireland. It is possible, therefore, that hazelnut production declined in response to the drought phase. However, Corylus remains the leading contributor to Irish pollen records during this time, and it is unlikely that the hazelnut supply dwindled to critical levels.

All things considered, despite lacking sufficient data with which to examine changes in diet during or subsequent to the $8.2 \mathrm{ka}$ Event, we can reasonably assume that the climate perturbations were significant enough to be perceived by the population in Ireland at the time. Furthermore, it is highly likely that food resources were impacted to some degree, although thus far our evidence is limited to some dips in hazel pollen representation. At this point in time, we can only speculate about how such changes might have impacted at a psychological level, as evidence for ritualised behaviour is severely lacking. There presently exists, however, little evidence to substantiate an argument for a critical reduction in environmental productivity that might have threatened human demographics in any substantial way.

\section{The Middle Neolithic}

The Early Neolithic in Ireland is both clearly defined and relatively restricted in its chronology to $c$. 4000-3600 cal BC. The period sees a 'veritable explosion' of activity entailing a distinctive settlement type (rectangular houses), landscape clearances for mixed farming and the initiation of court tomb construction at approximately 3750-3600 cal BC. ${ }^{36}$ A new material culture also appears, including pottery and a range of novel lithic forms. Some studies have suggested that this main pulse of Neolithic expansion began amidst a dry period identified through peatland proxies and subfossil tree population data, ${ }^{37}$ but as yet, the palaeoclimate of this interval has not been adequately investigated. By the Middle Neolithic (c. 3600-3100 BC), a decline in activity is observed in both the archaeological and palynological records, amidst what may have been a shift to wetter conditions, inferred by Whitehouse and colleagues from declining bog oak populations. ${ }^{38}$ Using multi-proxy data from two Irish bogs (Sluggan, Co. Antrim, and Fallahogy, Co. Londonderry), Roland and colleagues also identified a multi-centennial wet shift commencing sometime between 3550 $3000 \mathrm{cal} \mathrm{BC}$ which they dub the ' 5.2 ka event'. 39

In Whitehouse and colleagues' seminal analysis of Irish Neolithic sites, the archaeological decline occurs after $3400 \mathrm{cal} \mathrm{BC}$ and is inferred from the cessation of rectangular house construction and a decline in the construction of court tombs, a shift to more ephemeral occupation sites characterised by pits and postholes, and generally a major

${ }^{35}$ P.A. Tallantire, 'The early-Holocene spread of hazel (Corylus avellana L.) in Europe north and west of the Alps: an ecological hypothesis', The Holocene 12 (2002), 81-96.

${ }^{36}$ N.J. Whitehouse et al., 'Neolithic agriculture on the European western frontier: the boom and bust of early farming in Ireland', Journal of Archaeological Science 51 (2014), 181-205: 188; Cormac McSparron, 'Have you no homes to go to?', Archaeology Ireland 22, no. 3 (2018), 18-21. R.J. Schulting et al., 'New dates from the north and a proposed chronology for Irish court tombs', Proceedings of the Royal Irish Academy 112C (2012), 1-60.

${ }^{37}$ Chris Caseldine et al., 'Evidence for an extreme climatic event on Achill Island, Co. Mayo, Ireland around 5200-5100 cal. yr BP', Journal of Quaternary Science 20 (2005), 169-78.; Whitehouse et al., 'Neolithic agriculture', 194.

${ }^{38}$ Whitehouse et al., 'Neolithic agriculture', 199.

${ }^{39}$ T.P. Roland et al., 'The 5.2 ka climate event: Evidence from stable isotope and multi-proxy palaeoecological peatland records in Ireland', Quaternary Science Reviews 124 (2015), 209-23. 
reduction in the number of known archaeological sites..$^{40}$ McLaughlin and colleagues place the bottom of this trough in human activity at $3300 \mathrm{cal} \mathrm{BC}$, with an upturn in settlement evidence only after $3000 \mathrm{cal} \mathrm{BC} .^{41}$ This is complemented by palynological evidence indicating widespread forest regeneration signalling reduced levels of land-use in the final century. ${ }^{42}$ Smyth notes, however, that a shift to sod-built structures could explain the apparent decline in settlement evidence. ${ }^{43}$ And while court tomb construction may have waned, persistence of tomb use is apparently evident at some megalithic tombs, such as Parknabinnia, Poulnabrone and Poulawack, Co. Clare, where human bones remains have been dated to the closing centuries of the millennium. ${ }^{44}$ Exceptions to the pattern of decline in the pollen record include sequences from Glenulra and Garrynagran, Co. Mayo, where farming continues to be evident until around $3200 \mathrm{cal} \mathrm{BC}$, with the former sequence showing indications of drier conditions from around $3350 \mathrm{cal} \mathrm{BC},{ }^{45}$ and Ballynahatty, Co. Down, where signs of continued land-use through to the later fourth millennium BC can be seen. ${ }^{46}$

It is against the backdrop of this lull in activity that characterises the Middle Neolithic that the acme of the passage tomb tradition was reached, as exemplified by the Boyne Valley monuments, Knowth, Dowth and Newgrange. ${ }^{47}$ Indeed, the most complex tombs appear to have been built and used in the final centuries of the fourth millennium BC, ${ }^{48}$ corresponding to the nadir in many other aspects of the archaeological record. These major architectural attainments, showing strong connectivity with passage tomb builders along the Atlantic façade, seem to have been built during a widespread drought phase towards the end of the millennium. On Achill Island, Co. Mayo, Caseldine and colleagues report, on the basis of peat humification values, dry conditions from $3750 \mathrm{cal} \mathrm{BC}$ - at odds with the midmillennium $\mathrm{BC}$ wet-shift proposed by Whitehouse and colleagues - that became drier still around $3150 \mathrm{cal} \mathrm{BC}$, followed by an abrupt event (possibly a storm or series of storms) that triggered extensive soil erosion; the bog surface was subsequently colonised by pines. ${ }^{49} \mathrm{~A}$ significant growth anomaly characterised by reduced annual ring widths in the $3190 \mathrm{~s} \mathrm{BC}$ in Irish bog oaks and pines, mirrored in North American bristlecone pines, also points to an

${ }^{40}$ Whitehouse et al., 'Neolithic agriculture', 190, 199.

41 T.R. McLaughlin et al., 'The changing face of Neolithic and Bronze Age Ireland: A big data approach to the settlement and burial records', Journal of World Prehistory 29 (2016), 117-53: 143.

${ }^{42}$ Michael O'Connell and Karen Molloy, 'Farming and woodland dynamics in Ireland during the Neolithic', Biology and Environment: Proceedings of the Royal Irish Academy 101B (2001), 99-128; Whitehouse et al., 'Neolithic agriculture', 199.

${ }^{43}$ Jessica Smyth, 'The house and group identity in the Irish Neolithic', Proceedings of the Royal Irish Academy 111C (2011), 1-31.

${ }^{44}$ R.J. Schulting et al., 'New dates from the north', 33 (Fig. 10).

${ }^{45}$ Karen Molloy and Michael O'Connell, 'Palaeoecological investigations towards the reconstruction of environment and land-use changes during prehistory at Céide Fields, western Ireland', Probleme der Küstenforschung im Südlichen Nordseegebiet 23 (1995), 187-225; O'Connell and Molloy, 'Farming and woodland dynamics'.

${ }^{46}$ Gill Plunkett et al., 'Vegetation history at the multi-period prehistoric complex at Ballynahatty, Co. Down, Northern Ireland', Journal of Archaeological Science 35 (2008), 181-90.

${ }^{47}$ Gabriel Cooney et al., 'Ireland', in Alasdair Whittle, Frances Healy and Alex Bayliss, Gathering time: dating the early Neolithic enclosures of southern Britain and Ireland (Oxford, 2011), 562-669: 657.

${ }^{48}$ R.J. Schulting, 'Dating the construction of Newgrange', in A. Lynch, 'Newgrange revisited: new insights from excavations at the back of the mound 1984-5', Journal of Irish Archaeology 23 (2014), 46-50; Alex Bayliss and Muiris O'Sullivan, 'Interpreting chronologies for the Mound of the Hostages, Tara and its contemporary contexts in Neolithic and Bronze Age Ireland', in Muiris O'Sullivan, Chris Scarre and Maureen Doyle (eds), Tara - from the past to the future: towards a new research agenda (Dublin, 2013), 26-104; R.J. Schulting et al., 'Dating the human remains from Knowth', in George Eogan and Kerri Cleary (eds), Excavations at Knowth 6: the archaeology of the large passage tomb at Knowth, Co. Meath (Dublin, 2017). 331-79.

${ }^{49}$ Caseldine et al., 'Evidence for an extreme environmental event'. 
extreme event at a supra-regional scale, ${ }^{50}$ but the causes of such phenomena are elusive. In fact, this downturn is now known to be characterised by two phases in Ireland: an initial downturn at $3199 \mathrm{BC}$ is followed by a second at 3193 BC. ${ }^{51}$

To get a better handle on hydrological changes at the end of the fourth millennium $\mathrm{BC}$, we consider evidence for bog tree germination events. One of the most extensive collections of bog wood comes from Garry Bog, Co. Antrim, on which both oaks and pines were growing at this time. Oak start dates re-commence, after a hiatus, at $3451 \mathrm{BC}$, but recruitment is fairly evenly staggered until a $c$. 150-year hiatus beginning at $3081 \mathrm{BC}$. Oak assemblages from a small number of other bogs start to grow during the same timeframe (Fig. 4a). Pine start dates are recorded from $3418 \mathrm{BC}$, but the 3250 s stand out as having a slightly higher frequency of recruitment. At Ballymacombs More, Co. Londonderry, pine expansion seems to have commenced later at $3138 \mathrm{BC}$, and there is a steady recruitment thereafter until the early third millennium BC. Pine assemblages from elsewhere in the north of Ireland show a range of start dates in the final centuries of the fourth millennium $\mathrm{BC}$, all but one dating to after $3200 \mathrm{BC}$, continuing to $2925 \mathrm{BC}$ (Fig. 4b). The bog trees appear, therefore, to reflect a gradual transition to dry conditions suitable for oak to grow on the bogs from c. $3400 \mathrm{BC}$ and pine expansion following c. $3200 \mathrm{BC}$. These data are hard to reconcile with Roland and colleagues' peatland evidence for wetter conditions unless the latter corresponds with a reduction in oak and pine recruitment before $c$. $3400 \mathrm{BC}$ or after $2900 \mathrm{BC}$. A shift to drier conditions around $3200 \mathrm{BC}$ is also evident in English ${ }^{52}$ and $\mathrm{Scottish}^{53}$ tree-ring chronologies. The bog tree records mirror the peatland record from Achill Island: dry conditions, getting drier still before an extreme event (the nature of which is uncertain but which may have entailed increased storminess, as evidenced at Achill), followed by more pronounced dry conditions favourable to the expansion of pine. We believe that the more precisely dated evidence presented here does indeed point to a $5.2 \mathrm{ka}$ Event, but one characterised by dry rather than wet conditions.

What does this mean in terms of potential societal impacts? The archaeological record gives us little insight into the nature of settlement or economy at $3200 \mathrm{BC}$, and pollen records are generally rather mute in terms of human impacts at this time. As outlined above, the impetus for this 'bust' was in place several centuries before. The burial record provides hints that social changes accompanied the decline of the settlement evidence, with increasing complexity demonstrated by the passage tomb tradition. Importantly, as Carlin points out, the large passage tomb cemeteries, especially the sophisticated Boyne Valley monuments, and the mass burials in the Mound of the Hostages, Tara, Co. Meath, are not consistent with a reduced population. ${ }^{54}$ Given how little we know of the economic basis of the Middle Neolithic - apart from the fact that it was sufficiently non-intensive to escape notice in most pollen records - it is difficult to envisage how a drought phase might have impacted upon the subsistence base, but a hydrological drought need not equate to an agricultural one, particularly in non-intensive farming subsistence regimes. Quite possibly, however, a shift in climate regime could have stimulated an ideological transformation, including a greater preoccupation with seasonal cycles, encapsulated in monument orientations on key solar

${ }^{50}$ M.G.L. Baillie, and M.A.R. Munro, 'Irish tree rings, Santorini and volcanic dust veils', Nature 332 (1988), 344-6: 345; M.G.L. Baillie, 'A view from outside: recognising the big picture', Journal of Quaternary Science 14 (1999), 625-35: 627.

${ }^{51}$ Mike Baillie, personal communication.

${ }^{52}$ M.G.L. Baillie, A slice through time (London, 1995).

${ }^{3}$ A.K. Moir et al., 'Dendrochronological evidence for a lower water-table on peatland around 3200 3000 BC from subfossil pine in northern Scotland', The Holocene 20 (2010), 931-42.

${ }^{54}$ Neil Carlin and Gabriel Cooney, 'Transforming our understanding of Neolithic and Chalcolithic society (4000-2200 BC) in Ireland', in Michael Stanley, Rónán Swan and Aidan O’Sullivan (eds), Stories of Ireland's past: knowledge gained from NRA roads archaeology (Dublin, 2017), 23-56. 
events and megalithic art, the most spectacular examples of which emerge after $3200 \mathrm{BC}$. Such conjecture may not be testable, of course, but serves to draw attention to an alternative mode by which environmental changes could play a role in social transformations.

\section{The end of the Bronze Age}

Moving forward two millennia or so, the Dowris Phase, the belle époque of Irish Later Prehistory, comprises the final interval of the Irish Late Bronze Age, characterised by widespread settlement evidence, ${ }^{55}$ a thriving and creative metalwork industry ${ }^{56}$ and widespread forest clearance, ${ }^{57}$ dating to approximately $1000-800 \mathrm{BC}$. The reasons behind the collapse of the Bronze Age have long been debated, some proposing an environmental trigger, others pointing to the potential impacts of increasing social complexity or the emergence of iron-working. ${ }^{58}$ An environmental downturn at $850 \mathrm{BC}$ manifesting as cooler/wetter conditions in north-west Europe was reported by van Geel and his colleagues. ${ }^{59}$ In Ireland, tephrochronologically dated hydrological reconstructions from ombrotrophic (rain-fed) bogs suggest that the timing of this wet/cool shift was later by approximately a century. ${ }^{60}$ The event occurs close in time to the end of the Irish Late Bronze Age, but a detailed analysis of the dating evidence for the archaeological sites indicates that the seeming decline of the Bronze Age began closer to $900 \mathrm{BC}$, before the onset of the climatic 'deterioration'. ${ }^{61}$ At this time, the Irish peatland records indicate that instead conditions were relatively warm and dry. ${ }^{62}$ The inherent uncertainty in ${ }^{14} \mathrm{C}$-dated proxy records, despite the use of wiggle-match constrained tephrochronology in the Irish peatland sites, has led to a blurring of the precise timing of the '2.8 ka Event' (alternatively, '2.7 ka Event', which seems more accurate for Ireland at least), and the socio-economic significance of the warm/dry phase that apparently preceded this in Ireland during the ninth century BC has not yet been examined.

${ }^{55}$ V.R. Ginn, Mapping society: settlement structure in Later Bronze Age Ireland (Oxford, 2016)

${ }^{56}$ George Eogan, 'The Later Bronze Age in Ireland in the light of recent research', Proceedings of the Prehistoric Society 14 (1964), 268-351.

${ }^{57}$ Gill Plunkett, 'Land-use patterns and cultural change in the Middle to Late Bronze Age in Ireland: inferences from the pollen record', Vegetation History and Archaeobotany 18 (2009), 273-95.

${ }^{58}$ B.G. Scott, 'Some notes on the transition from bronze to iron in Ireland' Irish Archaeological Research Forum I (1974), 9-24; Barry Raftery, 'Dowris, Hallstatt and La Tène in Ireland: problems of the transition from bronze to iron', in S.J. de Laet (ed.), Acculturation and continuation in Atlantic Europe (Brugge, 1976), 189-97; B.G. Scott, 'The introduction of non-ferrous and ferrous metal technologies to Ireland: motives and mechanisms', in Michael Ryan (ed.), The origins of metallurgy in Atlantic Europe, Proceedings of the 5th Atlantic Colloquium (Dublin 1979), 189-204; Timothy Champion, 'From Bronze Age to Iron Age in Ireland', in M.L. Stig-Sørensen and R. Thomas (eds), The Bronze Age-Iron Age transition in Europe, British

Archaeological Reports International Series 483 (Oxford, 1989), 287-303; Barry Raftery, Pagan Celtic Ireland (London, 1994), 36-7.

${ }_{59}$ Bas van Geel, J. Buurman and H.T. Waterbolk, 'Archaeological and palaeoecological indications of an abrupt climate change in The Netherlands, and evidence for climatological teleconnections around $2650 \mathrm{BP}$ ', Journal of Quaternary Science 11, 451-60; Bas van Geel et al., 'The sharp rise of $\Delta^{14} \mathrm{C}$ ca. $800 \mathrm{cal}$ BC: possible causes, related climatic teleconnections and the impact on human environments', Radiocarbon 40 (1997), 53550.

${ }^{60}$ Plunkett, 'Tephra-linked peat humification records'; Graeme T. Swindles, Gill Plunkett and Helen Roe, 'A delayed climatic response to solar forcing at $2800 \mathrm{cal}$. BP: multi-proxy evidence from three Irish peatlands', The Holocene 17 (2007), 177-82; Gill Plunkett and Graeme T. Swindles, 'Determining the sun's influence on Late Glacial and Holocene climates: a focus on climate response to centennial-scale solar forcing at 2800 cal. BP', Quaternary Science Reviews 27 (2008), 175-84.

${ }^{61}$ Ian Armit et al., 'Rapid climate change did not cause population collapse at the end of the European Bronze Age', Proceedings of the National Academy of Sciences 111 (2014), 17045-9.

${ }^{62}$ Plunkett, 'Tephra-linked peat humification records'; Armit et al., 'Rapid climate change'. 
We turn again to the tree-ring data from Garry Bog, the site with the largest single dataset of bog oaks for this interval, and from which a peat humification record clearly shows a dry shift in bog surface wetness in the ninth century followed by a wet shift in the eighth century. The trees span a wide age range in both their start and death dates, commencing at $907 \mathrm{BC}$ but with a large concentration of trees commencing growth in the period 880-861 $\mathrm{BC}$ (Fig. 5) that is symptomatic of a change to more favourable germination conditions following a reduction in bog surface wetness. We dub this the 'Terminal Dowris Drought'. Thereafter, start dates are more or less evenly staggered until $750 \mathrm{BC}$, when a $c$. 40-year gap in germination can be observed between 751 and $713 \mathrm{BC}$, and another between 709 and 668 BC. It is notable that the timing of this first hiatus in germination is coeval with the $2.7 \mathrm{ka}$ wet-shift identified in the Irish peatland records and lends further support for the dating of this event to $c .750 \mathrm{BC} .63$

All in all, the precisely-dated tree-ring records from Garry Bog provide supporting evidence for the nature and timing of the hydrological swings observed at this and other sites in Ireland towards the end of the Late Bronze Age. There remains the difficulty of reconciling the timing of these environmental changes with the archaeological record. Dendro-dated trackways peak in the tenth century $\mathrm{BC}$, but decline during the ninth century $\mathrm{BC}$, although trackway construction may have continued using less substantial or non-oak materials for a time. ${ }^{64}$ Indeed, no dendro-dated archaeological sites of any kind are recorded between 856 and $685 \mathrm{BC} .{ }^{65} \mathrm{By}$ and large, then, dendro-dated sites substantiate the seeming reduction in building activities during the ninth century $\mathrm{BC}$ inferred from the ${ }^{14} \mathrm{C}$-dated archaeological record. ${ }^{66}$ The timing of this decline raises the question of whether a subsistence crisis triggered by a prolonged water deficit might have played a role in the collapse of the Irish Bronze Age.

Fortunately, this theory is testable, as some palaeohydrological records are directly associated with pollen records that can shed light on land-use and farming activities. Fig. 6 presents key anthropogenic indicators from six sites alongside their humification-derived index of relative bog surface wetness. ${ }^{67}$ Although peat humification is no longer a leading proxy for hydrological reconstructions, the dry to wet trends observed in these records have been replicated by semi-quantitative testate-amoebae reconstructions at Glen West (discussed here) and other Irish sites. ${ }^{68}$ The humification records suggest an earlier dry phase commencing around the eleventh century BC that brackets the start of the Dowris Phase but is distinct from the Terminal Dowris Drought. Strong inter-site correlations are afforded by the presence of the well-dated tephras GB4-150 (800-758 cal BC), Microlite (755-680 cal $\mathrm{BC})$ and BMR-190 (705-585 cal BC) ${ }^{69}$ Moreover, irrespective of chronological precision, uncertainty regarding the relative timing of the hydrological and land-use proxies is eliminated entirely by virtue of the two proxies being from the same peatland cores.

Expansions in land-use during the Late Bronze Age are evident to varying degrees in the pollen records, with the two western sites (Owenduff and Moyreen) showing strong increases in anthropogenic indicators as early as $c .1100 \mathrm{BC}$. In the more northerly sites, the

${ }^{63}$ Plunkett, 'Tephra-linked peat humification records'.

${ }^{64}$ Gill Plunkett et al., 'Environmental indifference? A critique of environmentally deterministic theories of peatland archaeological site construction in Ireland', Quaternary Science Reviews 61 (2013), 17-31.

${ }^{65}$ Based on Queen's University Belfast dendrochronological database.

${ }^{66}$ Armit et al., 'Rapid climate change'.

${ }^{67}$ G.M. Plunkett, 'Environmental change in the Late Bronze Age in Ireland (1200-600 cal. BC)', unpublished PhD, Queen's University Belfast, 1999; Plunkett, 'Tephra-linked peat humification records'; Plunkett, 'Land-use patterns'.

${ }^{68}$ Swindles et al., 'Centennial-scale climate change', Earth-Science Reviews 126 (2013), 300-20.

${ }^{69}$ G.M. Plunkett et al., 'New dates for first millennium BC tephra isochrones in Ireland', The Holocene 14 (2004), 780-6; Plunkett, 'Tephra-linked peat humification records'; Plunkett, 'Land-use patterns'. 
main expansions occur later, in the tenth (Claraghmore, Garry, Sluggan) or early ninth (Glen West) centuries BC. By and large, these expansions coincide with the Dowris Phase. Declines in activity are similarly time-transgressive, occurring during the ninth century $\mathrm{BC}$ at Claraghmore, Owenduff and Moyreen, and during the early eighth century BC at Garry, Sluggan and Glen West. Irrespective of any chronological imprecision, the timings of these declines have variable relationships to hydrological changes. At Moyreen and Owenduff, reduced human activity occurs within a wet phase; at Claraghmore, the start of the decline begins immediately prior to a shift towards drier conditions; and at Garry, Sluggan and Glen West, activity occurs during the spell of drier bog surface wetness. From an economic perspective, therefore, it would seem that changing levels of land-use were not driven by any specific climate event of the early first millennium BC.

Notwithstanding variations in the timing of changes in the pollen records, there were evidently widespread declines in farming levels (whether in expanse or intensity) in the period between 900 and $800 \mathrm{BC}$, coinciding with the fall-off in both ${ }^{14} \mathrm{C}$ - and dendro-dated archaeological sites and the inferred end of the Late Bronze Age. ${ }^{70}$ Clearly, we are witnessing at this time a social transformation that impacted settlement patterns, material culture and economy, and very possibly overarching social organisation. Thanks to the complementary pollen and hydrological records, we can disentangle the impact of environmental change and state that neither the Terminal Dowris Drought nor the 2.7 ka Event triggered a complete collapse of the subsistence base. A mixed subsistence economy and a largely self-sufficient mode of production ${ }^{71}$ may have ensured some degree of resilience against weather extremes. Moreover, we see evidence of recovery in the pollen records, with levels of land-use during the eighth and seventh centuries BC - the Early Iron Age - that are on par with pre-Dowris Phase activity. Similar recurrence of clearances and farming are evident in many Irish pollen records. ${ }^{72}$ The island was evidently not depopulated by any means, but those responsible for the clearings and farming left comparatively little trace in the material and settlement records. Their environmental footprint betrays their presence and underlines the inadequacy of inferring population collapses from periods of low visibility in the archaeological record.

Might then the Terminal Dowris Drought have influenced an ideological shift that undermined the social structure of the Dowris Phase? As for the Middle Neolithic, such a hypothesis can only be speculative, but it is worth noting the significance of wet places in the Late Bronze Age, and in particular their association with bronze and gold deposition. A drought manifesting in conjunction with the appearance of a new metal (iron) might have been perceived as portentous, enough perhaps to destabilise the existing social order.

\section{The impact of droughts in Irish prehistory: a summary}

We have examined three periods of Irish prehistory for which there is evidence of extended drought phases. While not denying that even short periods of drought can have severe detrimental effects on human populations, we find limited evidence that these drought phases

${ }^{70}$ Plunkett et al., 'Environmental indifference?'; Armit et al., 'Rapid climate change'.

${ }^{71}$ Ginn, Mapping society, 188.

${ }^{72}$ Karen Molloy and Michael O'Connell, 'Holocene vegetation and land-use dynamics in the karstic environment of Inis Oírr, Aran Islands, western Ireland: pollen analytical evidence evaluated in light of the archaeological record', Quaternary International 113 (2004), 41-64; Karen Molloy, 'Holocene vegetation and land-use history at Mooghaun, south-east Clare, with particular reference to the Bronze Age', in Eoin Grogan, The North Munster Project, Vol. 1: The Later Prehistoric landscape of South-East Clare, Discovery Programme Reports No. 6 (Dublin, 2005), 255-87; D.A. Weir, 'A palynological study of landscape and agricultural development in County Louth from the second millennium BC to the first millennium AD. Final report', Discovery Programme Reports 2 (1995), 77-126; Karen Molloy and Michael O'Connell, 'Boom or bust or sustained development? Fossil pollen records and new insights into Bronze Age farming in County Clare', Past Times, Changing Fortunes (2011), 57-71. 
were drivers of economic change. For the Mesolithic, the palaeoenvironmental evidence for changes associated with the $8.2 \mathrm{ka}$ Event strongly points to a centennial-scale drought phase, likely coupled with cooler conditions. The archaeological record for this interval, however, is simply too sparse to enable a critical evaluation of impacts these changes might have had either on subsistence or demographics. Nevertheless, there remains considerable scope to investigate the possible impact on aquatic and forest ecosystems through sedimentary records as a first step towards understanding potential repercussions for contemporary populations.

The Middle Neolithic decline appears to have commenced during a period of wetter conditions; there is conflicting evidence for hydrological changes in the centuries around $3400 \mathrm{BC}$, but a clearer picture emerges of a period of prolonged dryness from $3200 \mathrm{BC}$ following an extreme event of some sort. The environmental evidence supports the recognition of a $5.2 \mathrm{ka}$ Event in Ireland, but we propose that this event comprised an abrupt event in the $3190 \mathrm{~s} \mathrm{BC}$ that was followed by a multi-centennial drought phase. Again, a paucity of evidence for the prevailing economy limits our ability to infer the economic impacts of this series of changes. We consider instead the timing of the dry phase with respect to the emergence of greater complexity and solar symbolism within the passage tomb tradition, and hypothesise an ideological response to the challenges or opportunities that the dry conditions may have brought.

Finally, we examined for the first time the potential role of a drought phase on the demise of the Irish Late Bronze Age. While it appears that the Dowris Phase decline broadly coincided with the onset of drier conditions in the ninth century BC (the 'Terminal Dowris Drought'), we demonstrate variability in the relationship between the dry phase and changing levels of land-use, and we conclude that drought did not drive a collapse in the subsistence economy. We raise the possibility that the changing conditions could have had an impact on the social system or power relations at this time, an idea which, though speculative, is worth considering given the importance of wet places for metal deposition in the final stages of the Late Bronze Age.

To conclude, the palaeoenvironmental evidence points to recurrent and prolonged drought phases during the course of Irish prehistory. The examples we have examined lie close to periods of social transformation. We find little convincing evidence of population declines at these times, nor signs that the droughts exerted any specific influence on the subsistence economy, although for the Mesolithic in particular, we lack data to evaluate the impact on food resources. It may well be that the nature of the drought phases - the way in which precipitation was distributed throughout the year - did not noticeably disrupt the prevalent subsistence regimes. That said, the changes were almost certainly of sufficient magnitude to be perceptible to the generations who lived through these transitions, and we cannot exclude the possibility that the drought phases impacted on the worldviews of individuals, groups of individuals or entire societies to the extent that existing ideologies were transformed. It remains to be seen if and how present and future generations will alter their behaviour and belief systems in response to the unprecedented climate scenarios that await us.

\section{Reimagining environmental impacts on past societies}

Our analysis highlights the wealth of palaeoenvironmental archives available in Ireland with which to examine the occurrence and impact of past climate change, mainly those occurring over longer, multi-generational timescales - decades to centuries - but in some instances, over the course of a few years. Dendrochronological records are currently dominated by those from the north of Ireland, reflecting decades of research in this region, but there is considerable scope to extend this work to the Irish Midlands. In terms of marrying past climate change with the archaeological record, sedimentary records afford important 
opportunities to overcome the first critical hurdle, that of establishing the relative timing of any observed changes. That climate change happened in the past is indisputable, but much less certain is how such changes might have affected populations living in a world vastly different to that of today, or even of the recent past. As yet, we know little of the vulnerability, or resilience, of past populations living in lower densities, operating different modes of production under different group dynamics and socio-political regimes; of whether mobility was a solution, or indeed a problem, in the face of an environmental crisis; or of mortality and recovery rates following abrupt and severe events.

How to begin to address these complex issues? To the extensive vegetation histories offered by pollen records and the increasing number of peatland palaeohydrological reconstructions, a diverse range of emerging methodologies promises to provide greater and deeper insights into past environmental change and human activity. From a palaeoenvironmental perspective, it is through methods such as sedaDNA (ancient DNA reconstructions from sediment) and biomarker (organic molecule) analysis, combined with more traditional approaches, that we may be able to glean changes in the nature and scale of human activity through time, independently of dated archaeological sites, akin to the Late Bronze Age case study considered in this paper. Then, we may be able to 'see' elusive Mesolithic inhabitants, and track the 'disappearing' Neolithic and Bronze Age populations, pinpoint when and where pivotal changes occurred, and most importantly, directly evaluate changes in human activity - at least in terms of population levels and environmental impacts - with respect to manifestations of climate change. In the meantime, we need to adopt a more critical approach to our investigations of past climate impacts on societies, and consider too the impacts that the perception of those changes might have had on the populations who experienced them.

\section{Acknowledgments}

We wish to thank Siobhán McDermott and Libby Mulqueeny for their assistance in the production of the location map.

\section{Figure captions}

FIG. 1-Examples of palaeohydrological indicators in bogs. a) A stockpile of bog timbers extracted from Ballymacombs More, Co. Londonderry; b) A peat section in Sluggan Bog, Co. Antrim, showing large-scale change in peat humification (decomposition) from dark, well-humified peat to light, less decomposed peat (highlighted by arrow). More discreet changes in humification can be quantified using laboratory techniques; c) An example of a testate amoeba (Archerella flavum, previously called Amphitrema flavum), a microscopic single-celled organism found in abundance in peat bogs. Different species have specific hydrological preferences and sensitivities, rendering them an important indicator of past water levels on the bog. For instance, Archerella flavum usually indicates wet conditions (near-surface water tables) in peatlands.

FIG. 2-Outline of drought phases discussed in this paper, showing timing in relation to subfossil tree records (selected intervals only) and a compiled testate amoeba-derived water table reconstruction from Irish bogs 
illustrating average reconstructed depth of the water table below surface and highlighting (orange line) notable dry shifts in the record (based on Swindles et al., 'Centennial-scale climate change').

FIG. 3 - Location of sites from which subfossil trees remains discussed in this paper have been derived. 1) Altnahinch, Co. Antrim; 2) Ballinderry, Co. Londonderry; 3) Ballymacombs More, Co. Londonderry; 4) Blackwater, Co. Tyrone; 5) Derrycrow, Co. Armagh; 6) Eskragh, Co. Fermanagh; 7) Fallahogy, Co. Londonderry; 8) Garry Bog, Co. Antrim; 9) Sharvogues, Co. Antrim; 10) Sluggan Moss, Co. Antrim; 11) St Patrick's Road, Co. Armagh; 12) Tamlaghtmore, Co. Tyrone; 13) Tullyroan, Co. Armagh.

FIG. 4 -Distribution of start dates of a) bog oaks and b) bog pines between 3500 and 2901 BC, drawn from the Belfast Master Chronology database. All wood samples had centres present, and were sampled shortly above the buttress. Start dates are therefore likely to lag germination dates by not more than 10 years.

FIG. 5-Distribution of start dates from Garry Bog oaks dating to the period 1000-601 BC (data from the Belfast Master Chronology database). All wood samples had centres present, and were sampled shortly above the buttress. Start dates are therefore likely to lag germination dates by not more than 10 years.

FIG. 6 - Relationship between humification levels (shown as standardised light transmission values) (Plunkett, 'Tephra-linked peat humification records') and key anthropogenic indicators from six Irish bogs (dots indicate values of $<1 \%$ of total dryland pollen) (Plunkett, 'Land-use patterns'). All records are shown on a common age scale but the chronological precision of each site is variable to $c .30-50$ years. Inferred shifts to wetter bog surface conditions are highlighted in blue, and to drier conditions in orange. The positions of key tephras in each record are shown (triangle — Hekla 3; hexagon—GB4-150; square-Microlite; star-BMR-190): these tephras not only aid the dating of each sequence but also provide unequivocal tie-points between the records. 